\title{
Biskupska i prezbiterska \\ (ili svećenička?) \\ služba u Svetom pismu
}

\author{
AnĐelo MALY* \\ UDK: 27-23-722.52 • Pregledni članak \\ Primljeno: 12. listopada 2017. • Prihvaćeno: 18. lipnja 2018.
}

${ }^{*}$ Dr. sc. Anđelo Maly,

Katolički bogoslovni

fakultet Sveučilišta

u Zagrebu, Vlaška 38, 10000 Zagreb, Hrvatska, maly.angelo@gmail.com

Sažetak: Svoje razmišljanje o biskupskoj i prezbiterskoj službi u Svetom pismu autor započinje razlaganjem o terminološkoj distinkciji pojmova prezbitera, biskupa i svećenika. Prema svetopisamskim tekstovima one su pojmovno udaljenije od onoga što suvremeni čovjek misli kada govori o tim službama ili, bolje rečeno, osobama. Iz detaljne terminološke analize proizlazi kako u Svetom pismu postoji razlika izmedu riječi prezbiter i svećenik. Na temelju dobivenih rezultata, prva bi označavala osobu koja se brine za profano, dok bi se druga odnosila na osobu koja se brine za svete stvari. Biskup je, s druge strane, osoba koja nadgleda zajednicu. Na temelju biblijskih tekstova autor u drugome dijelu rada iznosi svjedočanstva o utemeljenju i razvoju svećeničke, prezbiterske i biskupske službe pokušavajući obrazložiti prethodno utemeljenu terminološku razliku, kao i uočljivu promjenu situacije u novozavjetno vrijeme. Činjenica koja je stalna jest da su službe svećenika, prezbitera i biskupa funkcionalno i pojmovno, barem prema onomu što donose tekstovi Svetoga pisma, postavile temelje za daljnja razmišljanja i teološka utemeljenja tih službi.

Ključne riječi: prezbiter, svećenik, biskup, biblijske institucije, biblijska teologija

\section{Uvod}

Refleksija o biskupskoj, prezbiterskoj i svećeničkoj službi u Svetom pismu zahtjevna je i ograničavajuća zadaća iz nekoliko razloga. Prvi je terminološke naravi jer se pod pojmovima biskupa, prezbitera i svećenika krije šire značenje 
od onoga na koje pojedinac misli kada kaže biskup i prezbiter i/ili svećenik. Postoje i povijesna ograničenja prema kojima su te institucije tijekom povijesti doživjele različite konotacije ovisno o kontekstu u kojem su nastajale i razvijale se. Treći je razlog interpretacijske naravi i povezan je sa službom svećenika, prezbitera i biskupa u smislu poteškoća razumijevanja njihovih funkcija u svjetlu aktualnoga poimanja njihove službe.

Iz navedenih razloga potrebno je stoga prvotno promotriti etimologiju pojmova svećenika, prezbitera i biskupa i potom pokušati dati biblijski pregled njihovih službi kako se oni spominju u biblijskoj tradiciji Staroga i Novoga zavjeta. Zatim, u posljednjem dijelu ovoga razmišljanja, potrebno je vidjeti kako je moguće povezati navedene službe u Svetom pismu sa suvremenim teološkim razmišljanjima.

\section{Terminologija}

Nemoguće je govoriti o službi biskupa, prezbitera i svećenika u Svetom pismu, a da se prvo ne osvrnemo na terminologiju. Govoreći o biskupu i prezbiteru i/ili svećeniku, prvo na što pojedinac pomisli jesu dva stupnja svetoga reda. Biskup tako, općenito govoreći, predstavlja visokoga dostojanstvenika u Katoličkoj Crkvi i nasljednika apostola, dok pojam prezbitera drugim riječima označava svećenika, službenika Crkve i djelitelja sakramenata. Međutim detaljnija analiza pojmova prezbiter i biskup upućuje na širi i drukčiji spektar značenja i podrijetla tih osoba.

\subsection{Prezbiter I/ILI SVEĆENIK?}

Potrebno se zapitati postoji li razlika između pojmova prezbiter i svećenik? Je li riječ o istoznačnicama ili su ta dva termina etimološki, ali i funkcionalno različiti? Naime u međusobnoj komunikaciji rijetko će neki crkveni službenik sebe predstaviti kao prezbitera, dok ćemo češće čuti kako se govori o svećenicima. Dakle razlika između prezbitera i svećenika postoji i ona je velika već na terminološkoj razini.

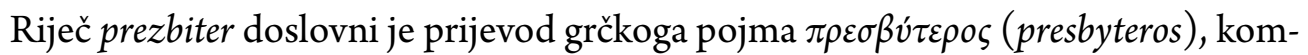
parativa pridjeva $\pi \rho \varepsilon \varepsilon \sigma \beta v \varsigma$ (presbys), a upotrebljava se u sljedećim slučajevima: ${ }^{1}$

1) da ukaže na starost neke osobe u odnosu na mlađu (usp. Lk 15, 25) ili da jednostavno znači starac u pozitivnom smislu riječi (podrazumijevajući dostojanstvo i čast; usp. Izr 20, 29; Sir 25, 4-6)

2) kao politički naslov kojim se opisuje predsjednik zajednice ili autonomni organ vlasti koji imaju administrativnu i sudsku službu u zajednici, zbog čega LXX

\footnotetext{
${ }^{1}$ Usp. G. BORNKAMM, $\pi \rho \varepsilon ́ \sigma \beta v \varsigma$, u: G. KITTEL, G. FRIEDRICH (ur.), Grande lessico del Nuovo testamento (= GLNT), XI, Brescia, 1977., 83-91.
} 


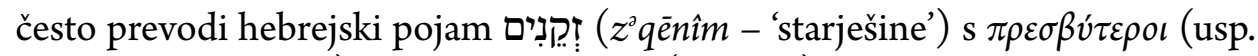

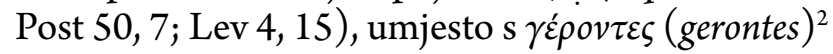

3) s dvostrukim značenjem pri čemu upućuje na nečiju staračku dob (usp. Post 18, $11 ; 19,4 ; 24,1 ;$ Iv 8, 9; 1 Tim 5, 1-2; Heb 11,2) ili je naslov za pojedinca koji obavlja povjerenu mu službu odgovornoga u zajednici (usp. 1 Pt 5, 5), često smatranoga nositeljem doktrinarne i normativne predaje (usp. Mt 15, 2; Mk 7, 3.5).

Prema navedenim slučajevima moguće je zaključiti kako je prezbiter onaj koji ima određeno dostojanstvo zahvaljujući povlaštenom položaju u društvu ili zajednici. Drugim riječima, čini se da prezbiter, odnosno starješina, u prvoj instanci predstavlja odgovornu osobu koja unutar naroda najvjerojatnije zbog svoga životnoga iskustva i krjeposti može davati važne savjete i smjernice. Starozavjetni tekstovi jako škrto svjedoče o socijalnim skupinama starješina i o njihovim grupacijama. Tek de-

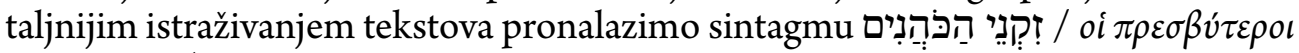

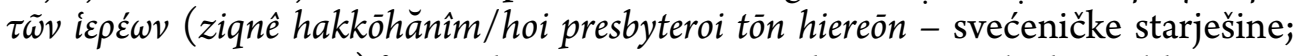
usp. $2 \mathrm{Kr} 19,2 ; \mathrm{Jr} 19,1) .{ }^{3}$ Navedena sintagma potvrđuje terminološku razliku između svećenika i prezbitera (starješine).

Iz prethodno navedene sintagme vidljivo je kako je hebrejska riječ za svećenika

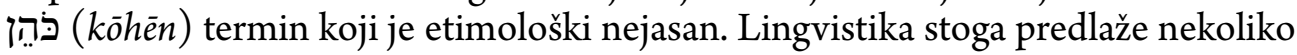
mogućnosti podrijetla riječi kōhēn: ${ }^{4}$

1) od akadskoga kânu koji u uzročnom glagolskom obliku znači 'klanjati se, služiti bogu'

2) od sirijskoga kahhēn koji osim 'biti svećenik' znači i 'usrećiti, obilovati'

3) od hebrejskoga glagola kûn koji znači 'stajati (pred Bogom), služiti' (usp. Pnz 10, 8) ili u neprijelaznom glagolskom obliku sa značenjem 'pripraviti' (usp. Sef 1, 7).

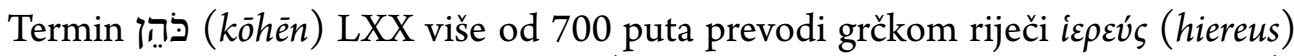

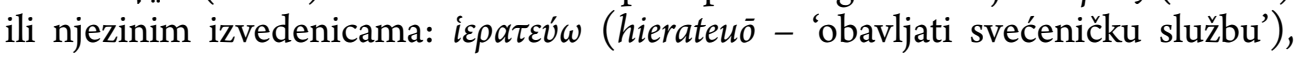

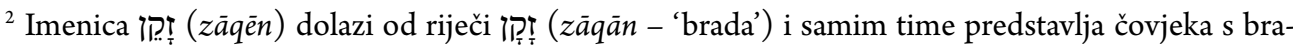
dom, uglavnom se pretpostavlja starije dobi, a samim time i čovjeka koji ima pravo sudjelovanja na narodnim skupštinama. Vidi J. CONRAD, זָָָז, u: G. J. BOTTERWECK, H. RINGGREN (ur.), Theological Dictionary of the Old Testament (= TDOT), IV, Grand Rapids (MI), 1980., 122-124.

${ }^{3}$ Moguće je da su postojale i proročke starješine, ali u tom slučaju tekst se koristi imenicom לִהָקָה (lahăq $\bar{a}^{h}$ - zbor; usp. 1 Sam 19, 20); vidi J. CONRAD, 128., זָזָז.

${ }^{4}$ W. DOMMERSHAUSEN, פהּן, u: G. J. BOTTERWECK, H. RINGGREN (ur.), TDOT, VII, Grand Rapids (MI), 1995., 66.
} 


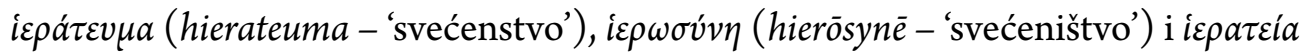
(hierateia - 'svećenstvo, svećenici'). ${ }^{5}$ Nema razloga da se ذَñ (kōhēn) prevodi s

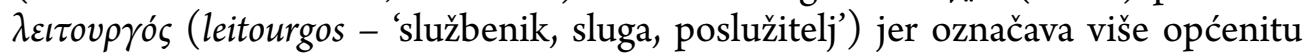
ulogu, nego liturgijsku. Jednostavni pojam iepeús (hiereus) označava i vrhovnoga svećenika, analogno poganskoj upotrebi pojma pontifex, a samim time se i umje-

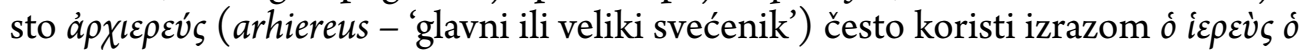

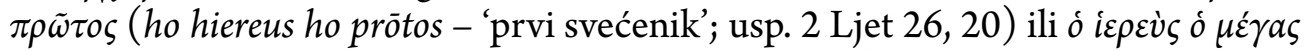
(ho hiereus ho megas - 'veliki svećenik'; usp. Lev 21, 10). ${ }^{6}$

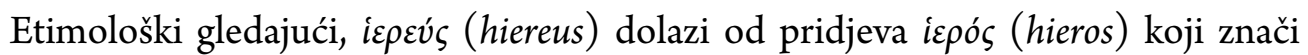
'svet, posvećen, častan' i samim time je moguće zaključiti kako svećenik mora biti povezan sa svetim. Vjerojatno se iz toga razloga u grčkom jeziku uz i̊pós (hieros) znaju naći i njegovi sinonimi $\theta \varepsilon \tilde{\varepsilon} o \varsigma$ (theios - 'božji, božanski') ili ă posvećen'). ${ }^{7}$ Svećeničku ulogu moguće je stoga povezati i shvatiti samo u kontaktu sa svetim. Svećenik je prema tomu osoba koja služi bogu/Bogu te posreduje između ljudi i božanstva, obavljajući svete obrede.

Iz navedene terminologije proizlazi važna činjenica, a ta je da svećenik predstavlja onoga koji se brine o svetome i prinosi žrtve, dok bi prezbiter (starješina) bio osoba koja je zadužena za organizaciju i upravljanje životom u zajednici. Polazeći od same terminologije, proizlazi kako je prva služba sakralna, a druga profana. ${ }^{8}$

\subsection{BISKUP}

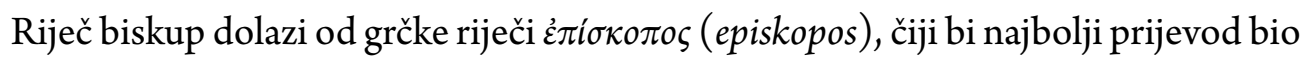
'nadglednik' ili 'čuvar'. Iz toga izvornoga značenja riječi u grčkom jeziku postupno se razvila dvostruka upotreba termina: ${ }^{9}$

1) kao nadglednik u smislu čuvara ili zaštitnika s funkcijom brige za nekoga (gr.

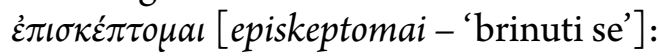

2) kao naslov kojim se opisuju različita zaduženja iz domene profanoga, najčešće tehničkih ili ekonomskih područja.

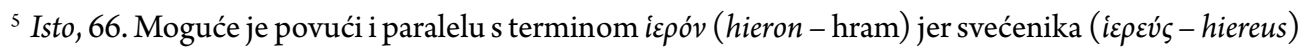
i njegovu službu najčešće povezujemo sa svetim mjestom, odnosno hramom.

${ }^{6}$ G. SCHRENK, iٔpev́s, u: G. KITTEL, G. FRIEDRICH (ur.), GLNT, III, Brescia, 1967., 854.

${ }^{7}$ ISTI, ípós, u: GLNT, III, 743.

${ }^{8} \gg$ Od grčke riječi prezbiter (starješina) dolazi u mnogim jezicima riječ priest (eng.), prete (tal.) i sl. Riječ svećenik (<lat. sacerdos) znači onaj koji daje sveto, onaj koji prinosi žrtve, stručnjak u svetim stva$r_{i m a \ll}$ (J.-L. SKA, Svećenik u Starom i Novom savezu, u: Služba Božja 49(2009.)2, 146.).

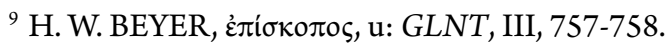




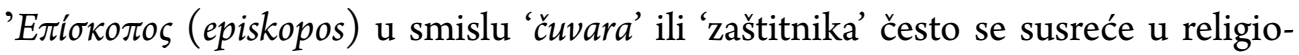
znim tekstovima jer se sama božanstva mogu definirati kao čuvari. Bog jer je čuvar ujedno je i sudac zlikovcima, te je u tekstu Job 20, 20 prijevoda LXX preveden kao $\dot{\varepsilon} \pi i \sigma \kappa o \pi \circ \varsigma$ (episkopos). ${ }^{10}$ Ljudi su nadglednici ( $\dot{\varepsilon} \pi i \sigma \kappa o \pi \circ l$ [episkopoi]) radova (usp. 2 Ljet $34,12.17$ ) te čuvari hrama ili svetinja (usp. Br 4, 16; $2 \mathrm{Kr} 11,18$ ).

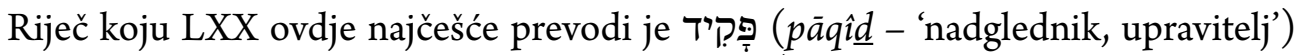
i njegove izvedenice, kao i particip glagola פָָָָּ (bāqar - 'istražiti; paziti; posjetiti; pohoditi'). Episkopos, odnosno biskup tako bi bio onaj koji nadgleda, pohađa i čuva pojedinca ili zajednicu. A kako se razvijala uloga episkopa i prezbitera, razmotrit ćemo u sljedećem koraku.

\section{Funkcija svećenika, prezbitera i biskupa u Svetom pismu}

U navedenoj terminologiji moglo se vidjeti kako je osnovno i prvo značenje prezbitera starješine i biskupa nadglednika povezano uz profano. Što onda sa svećeništvom i kako ga povezati uz te dvije kategorije? Jesu li s vremenom osobe prezbitera i biskupa postale svete institucije, odnosno povezane sa sakralnim i koji su događaji to uvjetovali? Sa sigurnošću možemo potvrditi da jesu iz jednostavnoga razloga, a taj je da je bilo potrebno kad-tad povezati svjetovno i duhovno s pomoću određenih institucija, odnosno osoba...

\subsection{SVeĆENIČKa SLUŽba ${ }^{11}$ U STARom ZaVjetu}

U povijesti ljudskoga društva, ali i religija, oduvijek su postojale osobe koje su imale privilegiran odnos sa svetim, s božanstvom. Već je u starom Egiptu postojala osoba koja se nazivala $w \cdot b$, 'čist čovjek' ili ona višega sloja nazivana hom-neter, 'sluga božanstva', često prevođena kao 'prorok..' ${ }^{12} \mathrm{U}$ organizaciji svećeništva niže svećenstvo bilo je organizirano prema koljenima (phyla) koja su se mijenjala na mjesečnoj razini, a $w \cdot b$ je izvorno bila laička služba, dok je jedini legitimni svećenik koji je mogao obavljati obrede u službi božanstva bio kralj koji je mogao imenovati svećenike kao svoje poslanike. U Mezopotamiji su postojali kultni službenici o čijim se funkcijama zna jako malo, stoga ondje ne pro-

\footnotetext{
${ }^{10}$ Isto, 772. Možda bi se i poznata narodna uzrečica: »Božje oko svuda gleda, sakrit mu se ništa ne $\mathrm{da} \ll$, mogla povezati s tim značenjem.

${ }^{11}$ Ne želeći na ovom mjestu naširoko i detaljno razlagati o svećeničkoj službi u Svetom pismu (što bi zahtijevalo studiju a se stante), već samo dati neke temelje za lakše povezivanje svećeničke, prezbiterske i biskupske službe, upućujemo na dvije značajne studije jednoga od najboljih poznavatelja starozavjetnoga i novozavjetnoga svećeništva: A. VANHOYE, Prêtres anciens, prêtre nouveau selon le Nouveau Testament, Paris, 1980.; ISTI, L’Epistola agli Ebrei. »Un sacerdote diverso «, Bologna, 2010.

12 J. BERGMAN, כּהּ, u: TDOT, VII, 61.
} 
nalazimo pojam za svećenika. Tako je najvjerojatnije jer nije postojala stroga razlika između političke i svećeničke službe, a kralj je, kao i u Egiptu, bio glavni službenik kulta i nosio je svećenički naslov. ${ }^{13}$ Tek u nekim feničkim, aramejskim i ugaritskim dokumentima možemo pronaći terminologiju koja se približava biblijskomu pojmu svećenika, ali prvotno u svojstvu vidioca ili proroka. ${ }^{14}$ Svećenik, bilo kralj ili neki poslanik kojega je imenovao, ujedno je bio odvojen od naroda jer je morao ući u kontakt s božanstvom. On je izdvojen od ostalih i to mora životom pokazati održavajući posebna pravila, odijevajući posebnu odjeću i boraveći u prostoru koji je za njega posebno određen.

Svećenička služba u organiziranom smislu također se ne pojavljuje odmah u Svetom pismu Staroga zavjeta. ${ }^{15} \mathrm{U}$ vrijeme praotaca, dok nema hrama, biblijski i arheološki izvještaji svjedoče o različitim kultnim središtima, prema čemu je jasno da je u početku bilo svećenika koliko je bilo takvih središta, a oni su uglavnom bili stranci (svećenik Melkisedek u Post 14, 18 ili Poti-Fer u Post 41, 50). ${ }^{16}$ Tek nakon centralizacije države javljaju se središnja svetišta: Betel i Dan na sjeveru i Jeruzalem na jugu. ${ }^{17}$ Kompleksnost odnosa između svećeništva i kulta sigurno se razvijala sukladno razvoju društva. Da bi očuvali funkcionalnost rodbinskih veza, pater familias bio je važan čimbenik u kultnim radnjama. ${ }^{18}$ Prvotni biblijski izvještaji spominju ovoga ili onoga patrijarha kako podiže oltar i time ustanovljuje kult Jahvi ondje gdje je nekad bilo sveto mjesto kanaanskih božanstava - Betel (Post 12, 8; 13, 4; 28, 18.22; 35, 7), Sihem (Post 12, 6-7; 33, 20) i Beer Šeba (Post 26, 25).

${ }^{13}$ Najviši duhovni dostojanstvenik zvao se en, a sanga je obavljao administrativne poslove. Išib je najvjerojatnije činio žrtve ljevanice i obrede čišćenja, dok je gala bio pjevač i pjesnik (H. RINGGREN, כּּה: u: TDOT, VII, 63-64.).

${ }^{14}$ M. HARAN, M. STERN, G. Y. BILDSTEIN, Priests and Priesthood, u: Encyclopaedia Judaica, F. SKOLNIK, M. BERENBAUM (ur.), XVI, Detroit, ${ }^{22007 ., ~} 513$.

${ }^{15}$ U civiliziranim narodima koji okružuju Izrael svećeničku službu često obavlja kralj kojemu pomaže hijerarhijski ustrojen i najčešće nasljedan kler koji tvori kastu, a ništa takvo ne javlja se u praotaca (usp. X. LÉON-DUFOUR (ur.), Rječnik biblijske teologije, Zagreb, 1993., 1301.). Sažeti prikaz povijesti izraelskoga svećeništva sve do danas dobro je prikazan u M. HARAN, M. STERN, G. Y. BLIDSTEIN, Priests and Priesthood, 521-527. O razvoju svećeničke službe u Starom zavjetu vidi A. VANHOYE, Sacerdozio, u: Nuovo dizionario di teologia biblica, P. ROSSANO, G. RAVASI, A. GIRLANDA (ur.), Cinisello Balsamo, 1988., 1387-1392.

${ }^{16}$ Usp. J.-L. SKA, Svećenik u Starom i Novom savezu, 134.

${ }^{17}$ Prije toga spominju se i druga svetišta: Šilo (1 Sam 1-3), Sihem (Suci 8-9), Beer Šeba (Am 8, 14),

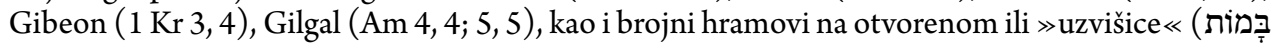
- bāmôt $t$ koje su zahtijevale službu jednoga ili više svećenika (usp. J. BLENKINSOPP, Sapiente, sacerdote, profeta. La leadership religiosa e intellettuale nell'Israele antico, Brescia, 2005., 120.).

${ }^{18}$ Isto, 123. 
Pojedine naznake o prvotnom svećeništvu mogu se pronaći na nekim mjestima. Neki Efrajimac, imenom Mika, postavio je jednoga od svojih sinova za svećenika u svetištu vlastite kuće (Suci 17, 1-6). I David je imenovao svoje sinove za svećenike postavljajući ih uz službeno svećenstvo čiji su predstavnici bili Sadok i Ebjatar (2 Sam 8,18$)$. U tim slučajevima pretpostavlja se kako nije bila nužna neka posebna sposobnost ili priprava za svećeništvo. Službeno svećeništvo pojavljuje se tek u pustinji kada ga Mojsije ustanovljuje posvećujući Levijevo pleme (usp. Izl 32, 25-29) kao izdvojeno i s posebnim položajem: primjerice ne će posjedovati nikakvu baštinu u Obećanoj zemlji i bavit će se samo kultom. ${ }^{19} \mathrm{U}$ to prvotno vrijeme, uz levitsko svećeništvo još uvijek postoji i obiteljsko svećeništvo (usp. Suci 6, 18-29; 13,$19 ; 17,5 ; 1$ Sam 7, 1). Tek u vrijeme monarhije nakon kralja Davida, kada Jeruzalem postaje bogoštovno središte, svećeništvo postaje organizirana institucija. ${ }^{20}$ Jačanjem državnoga aparata i uloga svećenika u svetištu postaje sve složenija. Jeru-

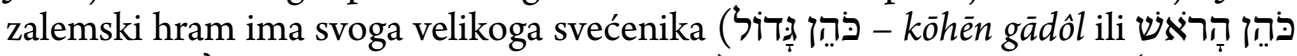

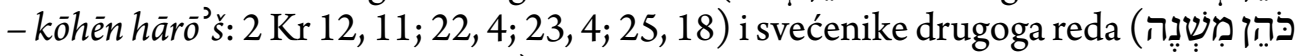
- kōhēn mišneh: $2 \mathrm{Kr} 23,4 ; 25,18$ ). U administraciji hrama i ekonomskim pitanjima

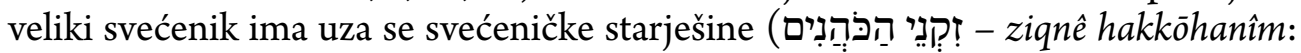
$2 \mathrm{Kr} 19,2$; Iz 37, 2; Jr 19, 1) te se spominje i vjerojatno još jedna niža kategorija, a to su svećenici »čuvari praga « $(2 \mathrm{Kr} 12,10 ; 22,4 ; 23,4 ; 25,18)$. Svi su oni bili državni službenici jer je jeruzalemski hram bio $\gg$ kraljevski i nacionalni hram « $($ Am $7,13)$, dok je veliki svećenik bio u posebnom odnosu s vladarom. ${ }^{21}$

Koje bi stoga bile svećeničke funkcije kako ih nalazimo u Svetom pismu Staroga zavjeta? Temeljni tekst za odgovor na to pitanje nalazi se u Ponovljenom zakonu:

$\gg$ Daj Leviju tvoje urime

i tvoje tumime čovjeku milosti svoje...

On uči Jakova tvojim odredbama

i Izraela tvojemu zakonu.

On podiže kâd $\mathrm{k}$ tvojim nosnicama

i paljenicu na žrtvenik ti stavlja $\ll(P n z$ 33, 8a.10).

Svećenik, jer zna kako ući u odnos s božanstvom, sa svetim, prvotno je čovjek obreda, više nego riječi i stoga može imati različite funkcije. Svećenik može prorokovati,

\footnotetext{
${ }^{19}$ Usp. J.-L. SKA, Svećenik u Starom i Novom savezu, 134. O povijesti svećeništva i levita u bibijskoj predaji, kao i njihovoj usporedbi vidi R. ABBA, Priests and Levites in Deuteronomy, u: Vetus Testamentum 27(1977.)3, 257-267.

${ }^{20} \mathrm{O}$ problematici svećeništva u povijesnim knjigama vidi J. G. McCONVILLE, Priesthood in Joshua to Kings, u: Vetus Testamentum 49(1999.)1, 73-87.

${ }^{21} \mathrm{~J}$. BLENKINSOPP, Sapiente, sacerdote, profeta, 134.
} 
ali samo jer zna što mu Bog govori, dok u isto vrijeme on može biti i vrač, iscjelitelj, čarobnjak i tomu slično. ${ }^{22}$

Jasno je vidljivo kako je jedna od osnovnih svećenička zadaća prorokovanje, odnosno on je osoba koja daje odgovore koji dolaze iz sfere božanskoga. Kada se god narod ili pojedinac nalazio pred nekom teškom odlukom, obraćali su se službenom posredniku da im kaže božansku namisao o rješavanju problema. Danovci se tako obraćaju svećeniku Miki riječima: »Upitaj Boga da znamo hoće li nam uspjeti put koji smo poduzeli.« (usp. Suci 18, 5-6). Samuelovo noćno viđenje možda predstavlja novu etapu u povijesti proroštva (1 Sam 3, 1b.19-21). Osim

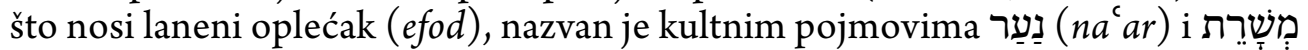
( $m^{\ni}$ šărēt) koji znače 'mladić' i 'poslužitelj' (1 Sam $\left.2,11.18 ; 3,1\right)$. Istim je pojmovima opisan Jošua kad služi u šatoru sastanka (usp. Izl 33, 11). ${ }^{23} \mathrm{I}$ kralj David dvaput pita Boga za uspjeh svoga vojnoga pohoda protiv Filistejaca (1 Sam 23, $2 ; 30,7-8)$, slično kao i Ahab i Jošafat ( $1 \mathrm{Kr} 20,13-14 ; 22,6 ; 2 \mathrm{Kr} 3,11)$. U traženju odgovora na svoje upite, na koje su najčešće dobivali potvrdni $(\gg$ da «) ili negativni ( $\gg$ ne $\ll$ ) odgovor, upotrebljavali su urim i tumim (usp. Izl 28, 30; Lev 8, 8; 1 Sam 14, 41-42). Što je to zapravo bilo, nitko ne zna točan odgovor. Možemo pretpostaviti da je riječ o tehničkim terminima koji su kasnije izišli iz uporabe jer se nitko s vremenom nije znao koristiti njima (usp. Ezr 2, 63; Neh 7, 65). ${ }^{24}$ Razlog je možda i taj da se s vremenom razvija služba svećenika, te on od proroka postaje učitelj, a javlja se i zasebna proročka karizma (usp. 2 Sam 7, 3.4-17; 12, 1-12.25; $1 \mathrm{Kr} 11$, 29-39; 13). U knjizi Ponovljenoga zakona nalazimo kako Mojsije povjerava Zakon (tôrā) svećenicima (usp. Pnz 31,9). Svećenik je tako čovjek nauke koji narod uči pravilnom ponašanju u odnosu prema zakonu. Također je čuvar zakona, posebice zakona povezanih sa svetošću (usp. Lev 7; 15, 28; $\mathrm{Br} 6,9-10){ }^{25}$ Usko povezana sa službom naučavanja jest i uloga sudca, zajedno sa starješinama naroda (usp. Pnz 17, 8-13; 21, 5). I svećenik Eli za vrijeme svoje svećeničke službe zaslužio je status sudca u Izraelu (1 Sam 4, 18), a prorok Ezekiel u uredbama o svećenicima donosi sljedeće: ${ }^{26} \gg$ Neka mi narod uče razlikovati sveto od nesvetoga, lučiti nečisto od čistoga. U parnicama oni neka budu suci: neka sude

\footnotetext{
${ }^{22}$ Usp. J.-L. SKA, Svećenik u Starom i Novom savezu, 133.

${ }^{23} \mathrm{~J}$. BLENKINSOPP, Sapiente, sacerdote, profeta, 125.

${ }^{24}$ Usp. W. DOMMERSHAUSEN, כּהָן, 67.; R. E. BROWN, Priest and Bishop. Biblical Reflections, Eugene (OR), ${ }^{2} 1999 ., 10$.

${ }^{25}$ Usp. C. DOGLIO, La Lettera agli Ebrei. Conversazioni bibliche di don Claudio Doglio, 11; vidi: http://www.symbolon.net/Nuovo\%20Testamento/San\%20Paolo/Lettera\%20agli\%20Ebrei/02La_tradizione_sacerdotale_dell_Antico_Testamento.pdf (23. 8. 2017.).

${ }^{26}$ M. HARAN, M. STERN, G. Y. BILDSTEIN, Priests and Priesthood, 519-520.
} 
po mojim zakonima; i neka čuvaju zakone i uredbe o svim mojim blagdanima i neka svetkuju moje subote.« (Ez 44, 23-24)

Treća zadaća svećenika koju Ponovljeni zakon stavlja na posljednje mjesto najpoznatija je i možda najopćenitija: svećenik je odgovoran za bogoslužje, prinošenje žrtava i blagoslivljanje naroda. ${ }^{27} \mathrm{U}$ vrijeme velikih slavlja i kraljevi su mogli prinositi žrtve, ali oni su vjerojatno za vrijeme obreda bili u pratnji svećenika. Kralj Uzija je na primjer prozvan da njemu ne pripada prinošenje žrtava, već svećenicima: »Nije tvoje, Uzijo, da kadiš Gospodinu, nego je to dužnost svećenikâ« (2 Ljet 26, 18b), a razlog tomu najvjerojatnije je bila veća svetost svećenika, opisanih sljedećim pojmovima: »koji dolazi blizu Gospodinu « (usp. Izl 19, 22; Lev 21, 17); » ulazi u svetište pred Gospodina « (usp. Izl 28, 35); »vrši službu « (usp. Izl 28, 35.43; Br 18, 7) i »uspinje se na žrtvenik « (usp. 1 Sam 2, 28). ${ }^{28}$ Prema biblijskim izvještajima postojale su i druge svećeničke službe, među kojima su blagoslivljanje naroda u Božje ime (usp. Pnz 10, 8; 21, 5), puhanje u trubu za vrijeme svečanosti (usp. $\mathrm{Br} 10,10$ ), nošenje Kovčega saveza (usp. Jš 3, 3-17), kao i raznovrsne obredne dužnosti (usp. Izl 30, 7-9; Br 8, 1-3; Lev 24, 5-9). U svim svojim dužnostima svećenici su, kao Božji službenici i sluge, uživali veću svetost od ostatka naroda, o čemu najviše govore tekstovi svećeničke predaje (Izl 29; Br 3-4; Lev 8) ${ }^{29}$ i prorok Ezekiel (Ez 40 - 48). ${ }^{30}$

Svećeničko poslanje podrazumijevalo je visoke zahtjeve, zbog čega je jasna proročka kritika svećeništva (usp. Hoš 4, 4-11; Ez 8; Sef 3, 4; Mih 3, 11; Mal 2, 1-9 i sl.). Svećenstvo je zaduženo da Izrael održi u stanju svetosti jer je Izrael sveti narod (usp. Izl 15, 5-6) koji pripada osobno Bogu jer njime upravljaju njegovi svećenici. ${ }^{31}$ Svećenik ima poput proroka strogo religiozno poslanje koje ispunjava u okviru institucija. Možemo stoga s pravom zaključiti da svećenik »nosi narodu Božju riječ u ime predaje, a ne u ime svog vlastitog poglavara; oživljava sjećanje na velike spomene svete povijesti i naučava Mojsijev Zakon. Prikazuje Bogu molitvu naroda u bogoslužju i na tu molitvu odgovara Božjim blagoslovom i podržava u izabranom narodu kontinuitet religioznog života slijedeći svetu predaju $\ll .32$

\footnotetext{
${ }^{27}$ J.-L. SKA, Svećenik u Starom i Novom savezu, 135.

${ }^{28}$ W. DOMMERSHAUSEN, ذּּהן 69.

${ }^{29}$ O biblijskoj tradiciji svećeničkoga pomazanja upućujemo na sažeto, ali iscrpno istraživanje D. FLEMING, The Biblical Tradition of Anointing Priests, u: Journal of Biblical Literature 117(1998.)3, 401-414.

${ }^{30}$ Vidi R. ABBA, Priests and Levites in Ezekiel, u: Vetus Testamentum 28(1978.)1, 1-9.

${ }^{31}$ J.-L. SKA, Svećenik u Starom i Novom savezu, 138.

${ }^{32}$ X. LÉON-DUFOUR (ur.), Rječnik biblijske teologije, 1307.
} 


\subsection{SveĆENiČKa SLUŽBa u Novom ZavJETU}

Stanje se u novozavjetno vrijeme vrlo malo promijenilo jer svećenici (članovi saducejske stranke) ${ }^{33}$ ostaju poslužitelji hrama (do 70 . godine!), dok Zakon i tradiciju proučavaju pismoznanci i farizeji. To je iznenađujuća činjenica jer svećeništvo napušta ono što se činilo njegovim bitnim poslanjem u Izraelu, a to je proučavanje Zakona, te se okreće više prinošenju žrtava i služenju u hramu, što su funkcije zajedničke svećenicima svih religija. ${ }^{34}$ Ujedno, Isus Krist svojim učenicima ne povjerava zadaću da prinose žrtve ili da sagrade novi hram. Njihovo je poslanje naviještanje evanđelja i stvaranje zajednice koja će živjeti po tom idealu, tako da evanđelje ne naviješta samo neki novi način obrednoga slavljenja Boga, već i novi način postojanja. ${ }^{35}$

Iako Isus nigdje $u$ evanđeljima ne govori za sebe da je svećenik ${ }^{36} \mathrm{ni}$ da su svećenici oni koje on izabire, Poslanica Hebrejima naširoko tumači Isusovo svećeništvo i koristi se svećeničkim rječnikom (usp. Heb 5, 1-10; 7, 20-28; 9, 6-7.11-14; 10, 11-14),37 odakle i proizlazi većina kasnije teologije o svećenstvu. Jedan od glavnih razloga zbog kojega se u Novom zavjetu ne govori o svećeničkoj službi kako ju mi zamišljamo jest taj da je služba i naslov svećenik bio preusko povezan sa svećenicima židovskoga hrama. Službe koje možemo povezati sa svećeničkim starozavjetnim službama u Novom zavjetu bile bi $\gg$ učenik-apostol $\ll$, $\gg$ prezbiter-nadglednik $\ll$ i $\gg$ slavitelj Euharistije $\ll .{ }^{38}$ Novozavjetni model svećenika kao učenika i apostola po-

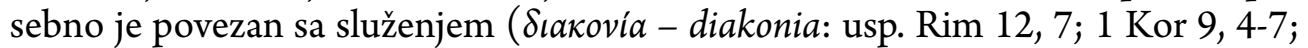

\footnotetext{
${ }^{33}$ Ime saduceji vjerojatno dolazi od heb. cadukim, ali nije sigurno je li sa značenjem pravedni ili pak od imena Sadok, u čijim je potomcima od pamtivijeka bila velikosvećenička služba ( $1 \mathrm{Kr} 2,35)$ (usp. A. REBIĆ, Biblijske starine, Zagreb, ${ }^{32} 2008 ., 241$.).

${ }^{34}$ J.-L. SKA, Svećenik u Starom i Novom savezu, 137.

${ }^{35}$ Usp. isto, 139.

${ }^{36}$ Prema rodoslovljima Isus ne pripada svećeničkom staležu jer potječe od plemena Judina, a ne Levijeva (usp. Heb 7, 13-14), a neki tumači evanđelja čak i smatraju da je Isus želio dokinuti svećenstvo (usp. I. ZIRDUM, Otajstvo Kristova svećeništva. Orisi za sustavnu teologiju svetog reda, u: Bogoslovska smotra 70(1999.)4, 578., nota 7.9).

37 »Poslanica Hebrejima obraća se kršćanima koji nisu uspijevali nadvladati traumu koju su doživjeli razorenjem hrama. Njezina je poruka jednostavna: ne žalite za hramom jer u svojoj vjeri imate nešto bolje: nebeski hram i jedincatu i konačnu žrtvu Isusa Krista. Poslanica Hebrejima čita otajstvo Isusove smrti i uskrsnuća kroz ključ obreda.« (J.-L. SKA, Svećenik u Starom i Novom savezu, 144.) Vidi A. VANHOYE, Sacerdozio, 1394-1396.

${ }^{38}$ Usp. R. E. BROWN, Priest and Bishop, 21-34. Ta posljednja svećenička funkcija kao onoga koji predslavi euharistiju (»lomi kruh«) uređuje se u prvim stoljećima jer u novozavjetnim spisima nigdje ne nalazimo opis ili imena onih koji su to činili.
} 
2 Kor 3, 7-9) i naviještanjem Riječi (usp. Dj 6, 2-4). Služenje se osim u konkretnoj situaciji pomaganja drugima pokazuje i molitvom:

»Tako ćete se u svemu obogatiti za svakovrsnu darežljivost koja se, našim posredovanjem, izvija u zahvalnicu Bogu. Jer ovo bogoslužno posluživanje ( $\dot{\eta}$

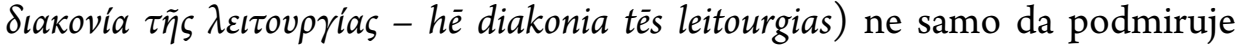
oskudicu svetih nego se i obilno prelijeva u mnoge zahvalnice Bogu « (2 Kor 9, 11-12).

Riječ je o svetoj i milosnoj službi, kako ju naziva apostol Pavao u Poslanici Rimljanima:

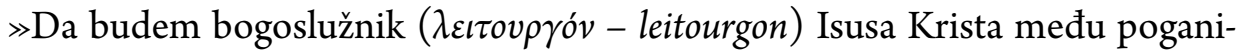

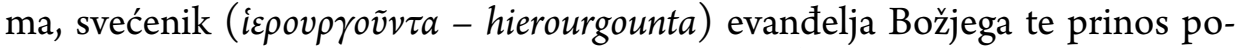
ganâ postane ugodan, posvećen Duhom Svetim « (Rim 15, 16).

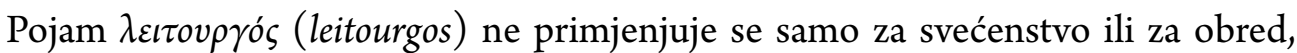
premda može imati u određenim kontekstima obredno značenje (usp. Heb 8, 2).

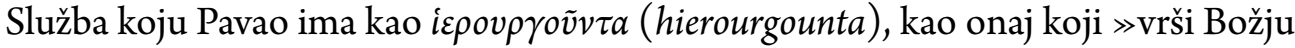
službu «, ne odnosi se na starozavjetno prinošenje žrtava uz paljenje prinosa, već na posvećivanje ljudi ognjem Duha Svetoga, a to se čini naviještanjem evanđelja. ${ }^{39}$

Dok su apostoli bili misionari koji su osnivali zajednice, rezidencijalnu svećeničku službu u tim zajednicama obavljali su prezbiteri nadglednici, čija je prvotna funkcija bila administrativna (usp. 1 Kor 12, 28; 1 Tim 3, 4-5; Tit 1, 9). Osim što su upravljali, oni su bili službeni učitelji u zajednici kao prenositelji ispravnoga nauka primljenoga od apostola, kao i uzori dobroga ponašanja i discipline. ${ }^{40}$ Precizirajući činjenice, učenici apostoli bili bi više karizmatski usmjereni, dok su prezbiteri nadglednici institucionalno orijentirani. Uspoređujući svećeničku službu kako je ona opisana u Starom i Novom zavjetu, vidimo da svećenik u konačnici ostaje onaj koji posvećuje narod kao učitelj i širitelj Riječi spasenja. U prvim kršćanskim zajednicama i njihovom institucionalizacijom stvaraju se određene strukture po uzoru na starozavjetne, prvotno sa smislom očuvanja predaje i prenošenja iste, a jedna od tih bila je i prezbiterat.

\subsection{Prezbiterska služba u Starom Zavjetu}

Govoreći o prezbiterima kao starješinama u Svetom pismu Staroga zavjeta, polazišna je točka da njihovo podrijetlo treba tražiti u patrijarhalnom poretku izraelskoga

${ }^{39}$ Usp. A. VANHOYE, Sacerdoti antichi e nuovo sacerdote secondo il Nuovo Testamento, 211.

${ }^{40}$ B. GLEESON, Ordained Persons and Their Ministries: New Testament Foundations and Variations, u: Australian eJournal of Theology 7(2006.)1, 7-8. (http://aejt.com.au/2006/vol_7_ no_1_2006/?article $=395138-12 \mathrm{k}-[\mathrm{html}]-16 \mathrm{Jan} 2012$ [2.9.2017.]). 


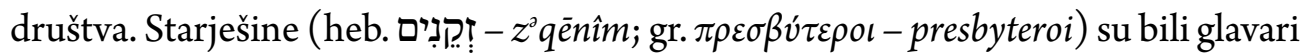
i samo predstavnici velikih obitelji ili naroda, bez ikakve upravne vlasti te uvijek podložni odgovornima za narod (kao Mojsije ili Jošua). ${ }^{41}$ Sugestivna je naredba kojom Bog zapovijeda Mojsiju da sabere sedamdesetoricu muževa $\gg$ između starješina izraelskih « $(\mathrm{Br} 11,16-17)$ na koje stavlja nešto od Mojsijeva duha te oni počinju prorokovati ( $\mathrm{Br} 11,24-25)$. Navedeni tekst je vjerojatno povezan $\mathrm{s}$ događajem sklapanja Saveza na Sinaju (usp. Izl 24, 1.9), jednako kao i s tekstom Izl 18, 13-27 u kojemu Mojsije na savjet svoga tasta Jitra među Izraelcima izabire sposobne ljude kao glavare (שָָׁרים - śárîm) narodu: tisućnike, stotnike, pedesetnike, desetnike i kao sudce za manje slučajeve (vidi Pnz 1, 9-18). ${ }^{42}$ Njihova uloga nakon osvajanja zemlje postaje sve važnija, te se tako oni bave političkim i vojnim pitanjima, obnašaju sudsku vlast (usp. Suci 11, 5; 2 Sam 3, 17; 5, 3) i još uvijek ostaju predstavnici naroda u ključnim događajima (usp. $1 \mathrm{Kr} 8,1.3$ ) ili podrška u važnim odlukama

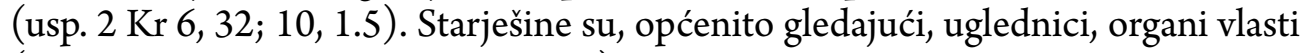
(usp. Jr 26, 17; Ez 8, 11, 12; Izr 31, 23) koji se brinu uglavnom za profano.

\subsection{Prezbiterska Služba u Novom zavjetu}

U povijesnom kontekstu služba starješina doživljava promjene tek u vrijeme Seleukovića (Antioh III., 223. - 187. pr. Kr.) kad se počinju nazivati vijećem staraca (gr.

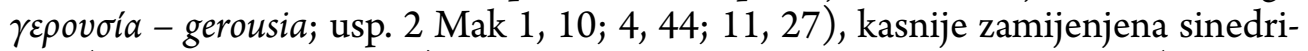

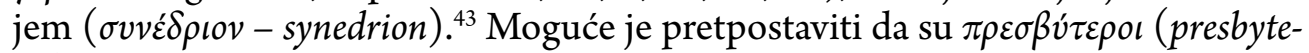
roi) bili laici tako da ih u novozavjetno vrijeme među sastavnicama sinedrija če-

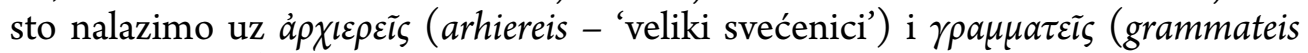
- 'pismoznanci'). ${ }^{44}$

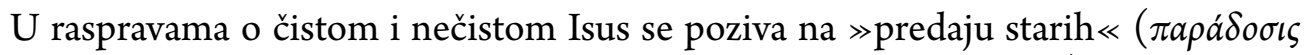
$\tau \tilde{\omega} v \pi \rho \varepsilon \sigma \beta v \tau \varepsilon \dot{\varepsilon} \rho \omega v$ - paradosis tōn presbyterōn: Mk 7, 1-23; Mt 15, 1-20) nazivajući je i predajom $\gg l j u d s k o m \ll(\tau \tilde{\omega} v \dot{\alpha} v \theta \rho \omega \dot{\omega} \omega \omega v$ - tōn anthrōpōn: Mk 7, 8.9.13). U kontekstu se ta Isusova rasprava ne odnosi na autoritet Zakona, već na primjenu istoga i tu-

\footnotetext{
${ }^{41}$ Usp. G. BORNKAMM, $\pi \rho \varepsilon ́ \sigma \beta v \varsigma, 92$. Biblijski tekstovi koji govore o njihovoj ulozi uz Mojsija i Jošiju brojni su, npr. prije izlaska (Izl 3, 16.18), za vrijeme sklapanja Saveza (Izl 24, 1), na skupštini u Šekemu (Jš 24, 1) i dr.

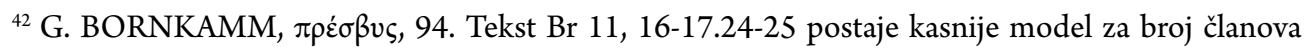
sinedrija i pojedinih udruženja od 70 članova (sudskih ili vojnih najčešće). O državnom ustroju u kratkim crtama vidi A. REBIĆ, Biblijske starine, 158.

${ }^{43}$ Lingvistički gledano, LXX daje terminu političko značenje prevodeći ponekad hebrejski $z^{3} q e ̄ n i ̂ m ~ s a$

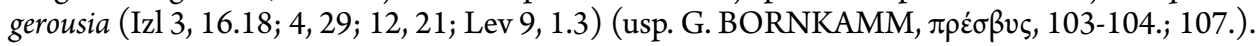

${ }^{44}$ Vidi Mk 11, 27; 14, 53; Lk 19, 47; 20, 1.
} 
mačenja unutar pojedinih židovskih skupina. ${ }^{45}$ Starješine se tako stavljaju u odnos s pismoznancima ili onima koji tumače ili potvrđuju zakonske predaje.

Prema izvještajima iz Djela apostolskih starješine susrećemo tek u trenutku kada im Pavao i Barnaba donose milostinju u Jeruzalem $(\mathrm{Dj} 11,30)^{46}$ i zatim u izvještaju o apostolskom skupu, kao i u pisanju apostolskih odluka (Dj 15; 16, 4). Posljednji put spominju se kada ih Pavao susreće u Jeruzalemu zajedno s Jakovom (Dj 21, 18). Starješine se, prema izvještajima u $\mathrm{Dj} 15 ; 16,4$, spominju zajedno $s$ aposto-

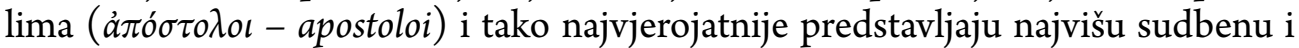
učiteljsku vlast u prvotnoj Crkvi. ${ }^{47}$ Očito je da je rast zajednice uvjetovao razvoj unutarnjega uređenja i nazočnost osoba različitih službi prema njihovoj dobi i sposobnosti.

Protopavlovske poslanice ${ }^{48}$ tako nigdje ne spominju starješine, već unutar zajednice postoje različite službe za koje Pavao upotrebljava naslove ovisno o funkciji koju obavljaju (Rim 12, 7-8; 1 Kor 12, 28; 1 Sol 5, 12) zahvaljujući darovima koje posje-

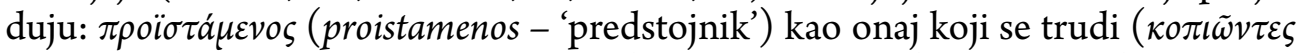

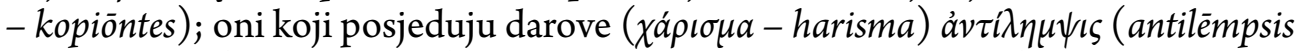

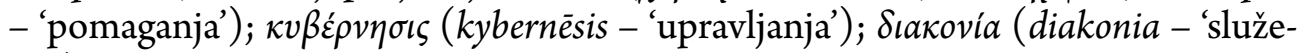
nja') i drugo. ${ }^{49}$

Prvi novozavjetni spis koji spominje prezbitersku službu jest Jakovljeva poslani-

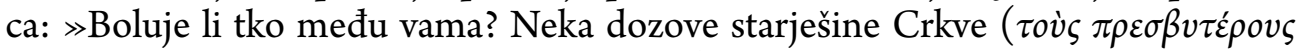
$\tau \tilde{\eta} \varsigma \dot{\varepsilon} \kappa \kappa \lambda \eta \sigma i a \varsigma$ - tous presbyterous tēs ekklēsias)! Oni neka mole nad njim mažući ga uljem u ime Gospodnje « (Jak 5, 14). Jasno je kako ovdje više nije riječ o osobama u odmakloj dobi s određenom profanom službom, već je riječ o konkretnom daru molitve koja je djelatna u njihovoj funkciji, odnosno prezbiteri imaju liturgijsku službu. U Prvoj Petrovoj poslanici prezbiterima su upućene sljedeće riječi:

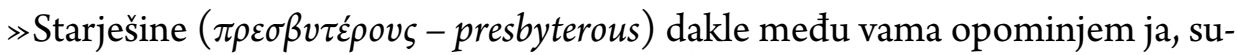
starješina ( $\sigma \nu \mu \pi \rho \varepsilon \sigma \beta \dot{\tau} \tau \varepsilon \rho \circ$ - sympresbyteros) i svjedok Kristovih patnja, a zato

${ }^{45}$ Usp. J. R. DONAUHE, D. J. HARRINGTON, Il Vangelo di Marco, Torino, 2006., 198-199.

${ }^{46} \mathrm{Ta}$ informacija o kolekti u Jeruzalemu već je u 11. poglavlju Djela apostolskih anakrona jer se ne poklapa s izvještajima iz Gal 1-2.

${ }^{47}$ Prema C. K. Barrettu »starješina $(z q n)$ se ne čini redovitom religioznom ili civilnom službom, već samo akademskom službom « (C. K. BARRETT, Atti degli apostoli, I, Brescia, 2003., 611.). Opservacija je djelomično točna ako uzmemo u obzir samo jednu funkciju starješina, a to je ona povezana s proučavanjem Zakona (Pisma). Kasnije u Dj 20, 17-38 efeške starješine nazvane su nadglednici-

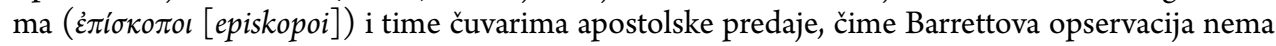
neko prečvrsto utemeljenje.

${ }^{48}$ Općeprihvaćeno se za protopavlovske uzimaju 1 Sol, 1 - 2 Kor, Rim, Gal, Fil, Flm.

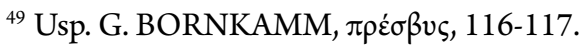


i zajedničar slave koja se ima očitovati: pasite povjereno vam stado Božje, nad-

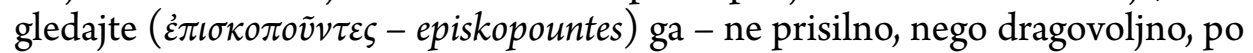
Božju (...) i ne kao gospodari Baštine, nego kao uzori stada « (1 Pt 5, 1-3).

Starješine koje Petar ovdje spominje nisu najstariji članovi zajednice, već njihovi vođe i njihova je uloga prvotno pastoralna. ${ }^{50}$ Prezbiteri su zaduženi da pasu povjereno im stado, ali njihovo mjesto u zajednici ovisi o stadu i Natpastiru (r. 4). Oni su među stadom da se brinu za njega, vode i brane ga, ali ne zbog vlastitoga naslova, već kao predstavnici istinskoga pastira i čuvara $(1 \mathrm{Pt} 2,25) .{ }^{51}$

$\mathrm{U}$ pastoralnim poslanicama upotreba pojma $\pi \rho \varepsilon \sigma \beta \dot{v} \tau \varepsilon \rho \circ \varsigma$ (presbyteros) nije jedinstvena. ${ }^{52} \mathrm{U} 1 \mathrm{Tim} 5,1(2)$ upućuje sigurno na starost (suprotnu mladoj dobi), dok u 4, 14 označava uobičajeni tehnički pojam onih koji upravljaju zajednicom i tvore skupštinu ( $\pi \rho \varepsilon \sigma \beta v \tau \varepsilon$ sıov - presbyterion). Po Pavlovu nalogu Tit mora po mjestima postaviti starješine (Tit 1,5) držeći se uputa koje je dobio (usp. Tit 1,6), a nalazimo i određene funkcije koje se na njih odnose: $\gg$ Starješine koji su dobri predstojnici dostojni su dvostruke časti, ponajviše oni koji se trude oko Riječi i poučavanja.« (1 Tim 5, 17; usp. 1 Sol 5, 12-13) Iznenađujuća je činjenica da se u pastoralnim posla-

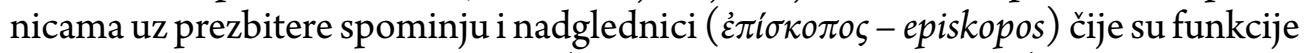
slične onima prezbitera starješina (usp. 1 Tim 3, 1-7; Tit 1, 7-9). Ipak se čini da bi bilo pogrješno odmah zaključiti kako su te dvije službe identične, na što i upućuje jednostavna činjenica da u pastoralnim poslanicama $\pi \rho \varepsilon \sigma \beta u ́ \tau \varepsilon \rho o l$ (presbyteroi)

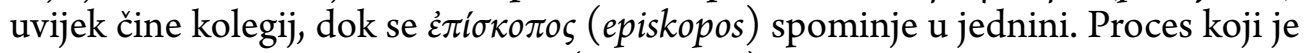
ovdje vidljiv jest taj da $\pi \rho \varepsilon \sigma \beta \dot{\tau} \tau \varepsilon \rho o l$ (presbyteroi) s vremenom više ne predstavljaju zbor odgovornih za zajednicu koji su postavili apostoli (usp. Dj 14, 23) ili njihovi nasljednici u lokalnim zajednicama (usp. Tit 1,5 ), već je bilo potrebno, sačuvavši patrijarhalni autoritet prezbitera, postaviti pojedince da obavljaju administrativne službe. Iz toga razloga u prvotnom crkvenom poretku nadglednici ( $\dot{\varepsilon} \pi i \sigma \kappa o \pi \circ \varsigma$ - episkopos) se u pastoralnim poslanicama opisuju kao oi $\kappa a \lambda \tilde{\omega} \varsigma \pi \rho \circ \varepsilon \sigma \tau \tilde{\omega} \tau \varepsilon \varsigma \pi \rho \varepsilon \sigma \beta \dot{v} \tau \varepsilon \rho o l$ (hoi kalōs proestōtes presbyteroi - 'starješine koje su dobri predstojnici') ili, drugim riječima, $\dot{\varepsilon} \pi \iota \sigma \kappa o \pi \circ \tilde{v} v \tau \varepsilon \varsigma$ (episkopountes - 'oni koji nadgledaju'). ${ }^{53}$

\subsection{BisKupsKa SLUŽBa u SVETOM PISMU}

Vidjeli smo kako se pojam $\dot{\varepsilon} \pi i \sigma \kappa o \pi o \varsigma$ (episkopos) u Svetom pismu postupno povezao uz pojam $\pi \rho \varepsilon \sigma \beta \dot{\tau} \tau \varepsilon \rho \circ$ (presbyteros) i stoga je dopušteno pitati se postoji li

\footnotetext{
${ }^{50}$ Usp. E. BOSETTI, Il pastore. Cristo e la chiesa nella Prima lettera di Pietro, Bologna, 1990., 187-188.

${ }^{51}$ Isto, 195.

${ }^{52}$ Usp. G. BORNKAMM, $\pi \rho \varepsilon \dot{\sigma} \beta \cup \varsigma, 124-128$.

${ }^{53}$ Isto, 128.
} 
točno određena služba u Svetom pismu koju bismo mogli povezati s biskupskom službom u modernom smislu riječi i koja bi ona bila.

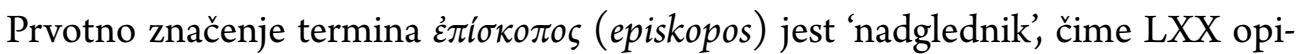

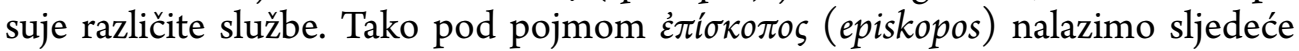

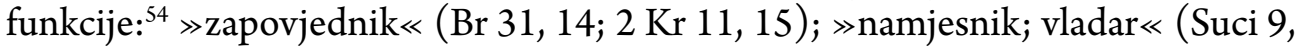
28; Iz 60, 17); »predstojnik « levitima (Neh 11, 22); »stražar Doma Gospodnjega $\ll(2 \mathrm{Kr} 11,18) ; \gg$ čuvar « svetih stvari $(\mathrm{Br} 4,16)$.

U Novom zavjetu termin pronalazimo svega pet puta ( $\mathrm{Dj}$ 20, 28; Fil 1, 1; 1 Tim 3, 2; Tit 1, 7; 1 Pt 2, 25), od čega je samo jednom primijenjen na Krista. U 1 Pt 2, 25 čitamo: $\gg$ Doista, poput ovaca lutaste, ali se sada obratiste $k$ pastiru i čuvaru

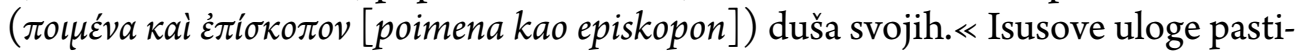
ra i čuvara usko su povezane (usp. Dj 20,28; $1 \mathrm{Pt} 5,2$ ), čime Isus posjeduje časni naslov onoga koji se posebnom pažnjom brine za duše svojih vjernika (usp. Sir 1, 6). ${ }^{55} \mathrm{U}$ ostalim navodima $\dot{\varepsilon} \pi i \sigma \kappa o \pi o \varsigma$ (episkopos) se odnosi na ljude, osobe koje su na čelu zajednice.

U tekstu iz Djela apostolskih, dok se obraća efeškim starješinama, Pavao govori: $\gg$ Pazite na sebe i na sve stado u kojem vas Duh Sveti postavi nadglednicima ( $\dot{\pi} \iota \sigma \kappa o ́ \pi o v \varsigma$ - episkopous), da pasete Crkvu Božju koju steče krvlju svojom.« (Dj 20, 28) Prezbiteri su tako ovdje u isto vrijeme episkopoi: prezbiteri starješine zbog položaja koji imaju u zajednici (sociološko obilježje), a episkopoi nadglednici zbog

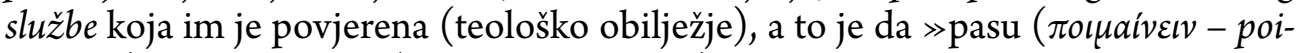
mainein) Crkvu Božju « (usp. 1 Pt 2, 25; 5, 2). ${ }^{56}$

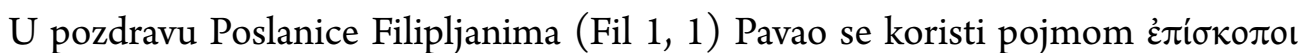
(episkopoi) zajedno uz pojam Sıákovor (diakonoi - 'poslužitelji'), što je jedino novozavjetno mjesto gdje se spominje takav slijed (u pastoralnim poslanicama uz njih će biti navedeni i $\pi \rho \varepsilon \sigma \beta \hat{\tau} \tau \varepsilon \rho o \iota$ [presbyteroi]). Ovdje je nemoguće prevesti termin episkopoi kao 'biskup' jer još uvijek ne postoji eklezijalna razlika među biskupima, đakonima i prezbiterima kakvu nalazimo u pastoralnim poslanicama. Zato služba episkopa i đakona treba proizlaziti iz civilnoga konteksta rimske provincije Filipa u kojoj se susreću funkcije nadgledanja i služenja osobama i dobrima. ${ }^{57}$

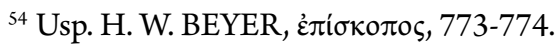

${ }^{55}$ Značenje koje se pridaje tom Isusovu naslovu slično je onomu koje se pridaje Bogu u Starom zavjetu (usp. isto, 775.).

${ }^{56}$ Pavao može prozvati starješinama samo one koji su već izabrani silom Duha Svetoga (vidi C. K. BARRETT, Atti degli apostoli, II, Brescia, 2005., 1141-1142.).

${ }^{57}$ Usp. A. PITTA, Lettera ai Filippesi. Nuova versione, introduzione e commento, Milano, 2010., 60-61. 
Posljednja dva spomena termina episkopos nalazimo u pastoralnim poslanicama.

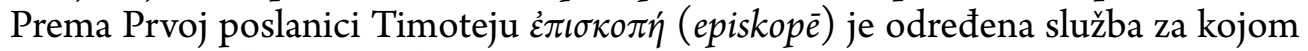
se može težiti $(1 \operatorname{Tim} 3,1)$ i za koju je potrebno imati određene kvalitete i krjeposti (usp. 1 Tim 3, 2-7).$^{58}$ Na konkretan način opisani su svi ljudski uvjeti, ali ne i zaduženja (osim upravljanja) koje pojedinac mora ispunjavati ako želi biti nadglednikom. Za službu nadglednika više se ne spominje uloga Duha Svetoga u njihovu izabiranju, već samo ljudske kvalitete. Iz toga je moguće vidjeti da je razvoj te službe određen potrebama svakodnevnoga života. ${ }^{59}$ Zahtjevi da netko postane prezbiter starješina u Tit $1,5-9^{60}$ slični su zahtjevima za nadglednike u 1 Tim 3, 2-7. Zanimljivo je primijetiti kako se u Tit 1, 7 iznenada umjesto $\pi \rho \varepsilon \sigma \beta \dot{\tau} \tau \varepsilon \rho \varsigma$ (presbyteros) nalazi $\dot{\varepsilon} \pi i \sigma \kappa o \pi$ (episkopos), jedno novo svjedočanstvo prema kojemu očito ta dva termina označavaju istu službu, odnosno termin episkopos samo je naslov za prezbitere u njihovoj pastoralnoj službi (usp. 1 Tim 5, 17). ${ }^{61} \mathrm{U} 1$ Tim 3, 2 i Tit 1, 7 upotrebljava se jednina $\delta \dot{\varepsilon} \pi i \sigma \kappa o \pi \circ \varsigma$ (ho episkopos), odnosno općenito se govori o službi, te je nemoguće razmišljati o broju episkoposa u jednom mjestu. ${ }^{62}$ Čini se da osnovna služba nadglednika (episkoposa), kako je opisana na stranicama Novoga zavjeta, nije bila predvođenje slavlja ili dijeljenje sakramenata, već je služila za izgradnju zajednice. Tek s vremenom episkopos kao naslov za biskupa preuzima važniju ulogu i počevši od 3. stoljeća povezuje se uz liturgijsku ulogu. ${ }^{63}$ Obavljanje biskupske službe uz prezbitere (svećenike) međutim je kolegijalno i jedna je od prvotnih zadaća biskupa poučavanje i odgajanje kršćanskoga naroda.

\footnotetext{
58 »Treba stoga da nadglednik bude besprijekoran, jedne žene muž, trijezan, razuman, sređen, gostoljubiv, sposoban poučavati, ne vinu sklon, ne nasilan nego popustljiv, ne ratoboran, ne srebroljubac; da svojom kućom dobro upravlja i sinove drži u pokornosti sa svom ozbiljnošću - a ne zna li netko svojom kućom upravljati, kako će se brinuti za Crkvu Božju? - ne novoobraćenik da se ne bi uzoholio i pao pod osudu đavlovu. A treba da ima i lijepo svjedočanstvo od onih vani, da ne bi u rug upao i zamku đavlovu. $\ll(1 \operatorname{Tim} 3,2-7)$

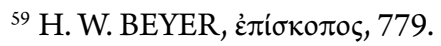

${ }^{60} \gg$ Poradi toga ostavih te na Kreti da urediš preostalo te po gradovima postaviš starješine kako sam ti ja odredio: je li tko besprigovoran, jedne žene muž, jesu li mu djeca vjernici i ne pod optužbom raskalašenosti ili nepokorna... Jer nadstojnik kao Božji upravitelj treba da bude besprigovoran: ne samoživ, ne jedljiv, ne vinu sklon, ni nasilju, ni prljavu dobitku, nego gostoljubiv, ljubitelj dobra, razuman, pravedan, svet, uzdržljiv, priljubljen uz vjerodostojnu riječ nauka da može i hrabriti u zdravom nauku i uvjeravati protivnike.« (Tit 1, 5-9)

${ }^{61} \gg$ Starješine koji su dobri predstojnici dostojni su dvostruke časti, ponajprije oni koji se trude oko Riječi i poučavanja.«

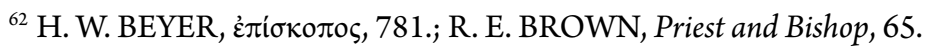

${ }^{63}$ Usp. J.-L. SKA, Svećenik u Starom i Novom savezu, 146-147.
} 


\section{Zaključak}

U ovom izlaganju pošli smo od pretpostavke da Sveto pismo često govori o prezbiterima i biskupima i njihovoj službi, ali već se u samom početku rada ispostavilo da je teško govoriti o njima jer se pojmovi prezbitera i biskupa često terminološki podudaraju. Iz toga razloga bilo je potrebno uvrstiti u naše razmišljanje i govor o svećenicima kao o posebnoj kategoriji (prvotno terminološki gledajući). Pojedinac može ostati zbunjen i još se uvijek pitati: Što ili tko su onda biskup/i, prezbiter/i i svećenik/ci u Svetom pismu? Tko je tko ili što u cijeloj toj priči? Je li riječ o osobama, institucijama, službama ili nečemu trećemu?

U odgovoru na ta pitanja potrebno je shvatiti kako je oduvijek svaka zajednica trebala imati svoje predvodnike, odnosno osobe koje će upravljati životom u zajednici. Život je, naravno, trebalo osmisliti institucionalno i duhovno ili, drugim riječima, bile su potrebne osobe koje bi se brinule za vremenito i osobe koje bi se brinule za sveto. Kao u svim kulturama tako je i u onoj biblijskoj svećenik prvotno bio osoba čija je služba bila briga za sveto (lat. sacrum): sveta mjesta, svete činove, svete stvari. Upravo to je bila prvotna i osnova svećenička služba - ući u kontakt s najsvetijim, s božanstvom. Sveto je odvojeno od naroda koji je profan (etimološki pro-fanum, 'ono što stoji ispred hrama') i samim time u povlaštenom položaju. Svećenik u tom smislu postaje posrednik između božanstva (Boga) i ljudi, ali je ujedno povezan i s jednom i s drugom stvarnošću (usp. Heb 5, 1-4). Iz toga razloga svećenik je ujedno i učitelj koji narod uči pravilima ponašanja prema svetomu. Svećenik je dakle, jednostavnije rečeno, onaj koji bi trebao posvećivati narod i učiti ih Božjem zakonu.

Osim službe posvećivanja važna je tijekom biblijske povijesti bila i služba upravljanja. Tu su službu, osim kraljeva koji su nekad obavljali i svećeničku službu, činili njihovi namjesnici. Neki među njima bili su dobro upućeni u nauku, administraciju i sudstvo, ali i u samo upravljanje zajednicom. Oni su se nazivali starješinama, prezbiterima, kako nalazimo u svetopisamskim tekstovima. Ti su predstavnici naroda s vremenom postali složenija institucija na čijem su čelu bili nadglednici, biskupi. Njihova je služba ponajviše služila izgradnji zajednice. O njihovoj službi nalazimo nekoliko rijetkih svjedočanstava na stranicama Novoga zavjeta. Možda bi bilo najbolje njihovu službu opisati kao »čuvari stada « (usp. 1 Pt 5, 2) koje im je povjereno. Oni su trebali biti uzorom zajednice i čuvarima svete predaje.

Promatrajući svetopisamske izvještaje i navedenu terminologiju, vrlo je diskutabilno među biblijskim tekstovima (napose novozavjetnima) tražiti strogi pojmovni i funkcijski kontinuitet među biblijskim pojmovima i funkcijama svećenika, prezbitera i biskupa te njihovim današnjim službama. Većina njihovih službi može se povezati s budućim teološkim razmišljanjima (onima nakon nastanka novozavjetnih spisa). 
Govoriti stoga o svećenicima općenito, svećenicima prezbiterima ili biskupima prezbiterima na osnovi svetopisamskih tekstova ostaje vrlo složena zadaća. Činjenica koja je stalna jest da je bilo svećenik, svećenik prezbiter ili biskup prezbiter institucija koja se brine (ili bi se trebala brinuti) za duhovno, a ne toliko za vremenito ili u vremenu. ${ }^{64}$

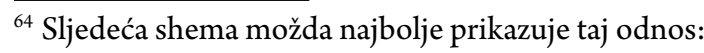

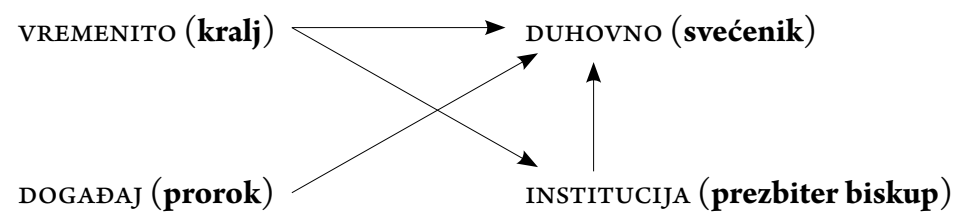




\title{
BISHOPS AND PRESBYTERS (OR PRIESTS?) AND THEIR MINISTRIES IN THE HOLY SCRIPTURE
}

\author{
Anđelo MALY*
}

Summary: It is quite difficult to speak about bishops and presbyters and their ministries in the Holy Scripture since biblical terminology explains their functions quite different than they are known today. According to this, the author primary emphasizes the terminology and some scriptural evidences of ministries in examination. The author explains words such as presbyter, bishop (episkopos) and priest, showing in the first instance how the biblical word for presbyter (=elder) diverges from the biblical word priest (kōhen; hiereus). Correspondingly, the biblical word episkopos (bishop) has not the same modern meaning as it has today, where represents the third grade of ordained minister, while in the Bible its meaning is a supervisor or protector of community. It is possible to say, concludes the author, that the office of bishop (episkopos) and presbyter (=elder) should be considered in profane sense of duty, while priest (kōhèn; hiereus) deals with sacred things. Successively, grounding the evidences upon biblical texts, the author gives some clarification about development of the priestly, presbyterian and bishop's offices, both in the Old and in New Testament. The scriptural data reveal that those offices stands and evolves in response to a variety of needs and the leadership in the community. In conclusion, the author asserts that is quite difficult to establish the safe terminological and functional link between biblical terms and duties of priest-presbyter-bishop and their actual offices. At least, according to the Scripture, it is possible to say that a priest, priest-presbyter or a bishop-presbyter should be considered as offices that take care more for a sacred and spiritual things than for a temporal things. Their ministries (as known today) are better mostly linked with successive theological reflections, when they became more ordered, uniformed and regulated.

Keywords: presbyter, priest, bishop, biblical institutions, biblical theology.

* Anđelo Maly, Ph. D., Catholic Faculty of Theology, University of Zagreb, Vlaška 38, 10000 Zagreb, Croatia, maly.angelo@gmail.com 